\title{
Okul Öncesi Eğitim Alma Süresinin Çocukların Sınıf Kurallarına Uyum ve Okul Motivasyonlarına Etkisinin Öğretmen Görüşlerin Göre İncelenmesi
}

\author{
Canan CESUR \\ MEB, Gürteks Gülşen Özkaya Anaokulu, Gaziantep \\ canancesur@live.com \\ ORCID ID: https://orcid.org/0000-0003-2675-1040 \\ Mehmet Kaan DEMIR \\ Çanakkake Onsekiz Mart Üniversitesi, Temel Eğitim Bölümü, Çanakkale \\ mkdemir2000@yahoo.com \\ ORCID ID: https://orcid.org/0000-0001-8797-0410
}

\begin{tabular}{lrr} 
Araştırma Makalesi & DOI: $10.31592 /$ aeusbed.643778 \\
\hline Geliş Tarihi: 06.11.2019 & Revize Tarihi: 24.01 .2020 & Kabul Tarihi: 27.01.2020
\end{tabular}

\section{Atıf Bilgisi}

Cesur, C. ve Demir, M. K. (2020). Okul öncesi eğitim alma süresinin çocukların sınıf kurallarına uyum ve okul motivasyonlarına etkisinin öğretmen görüşlerin göre incelenmesi. Ahi Evran Üniversitesi Sosyal Bilimler Enstitüsü Dergisi, 6(1), 103-122.

\section{ÖZ}

Bu çalışma, okul öncesi eğitim süresinin, çocukların okul motivasyonlarını ve kurallara uyum becerini nasıl etkilediğine dair okul öncesi öğretmenlerinin görüşlerini araştırmayı ve değerlendirmeyi amaçlamıştır. Çalışmanın evrenini Gaziantep ili Şehitkamil ilçesinde bulunan bağımsız anaokullarında ve bünyesinde anasınıfı bulunduran devlet okullarında çalışmakta olan okul öncesi öğretmenleri oluşturmaktadır. Bu evren içerisinden 161 öğretmen örneklem olarak seçilmiştir. Araştırmaya katılan öğretmenlere araştırmacı tarafindan hazırlanmış olan okul öncesi eğitim süresine dair; "Okul Öncesi Eğitim Süresinin Çocuklara Etkisine Dair Öğretmen Görüşleri Ölçeği” uygulanmıştır. Uygulama sonunda elde edilen verilerin analizinde SPSS 21 programından yararlanılmıștır. Verilerin analizinde öncelikle katılımcıların demografik özelliklerine göre frekans ve yüzde analizleri yapılmıştır. Daha sonra okul öncesi eğitim süresi ile ilgili karşılaştırma yapan 17 adet sorunun frekans ve yüzde değerlerine bakılmıştır. Son olarak geliştirilen ölçek ile toplanan verilerinin dağılımlarına bakılarak sonraki adımda hangi analiz tekniğinin kullanılması gerektiği belirlenmiştir. Normalliğe bakıldıktan sonra demografik özelliklerle öğretmen görüşleri arasında herhangi bir farklılaşma olup olmadığına bakılmak için için bağımsız gruplar için t-Testi ve ANOVA testi uygulanmıştır. Yapılan testler sonucunda elde edilmiş olan verilerin analizlerine göre araştırmaya katılan öğretmenler genel olarak çocukların okul öncesi eğitime 36-48 ayda başlamasının 60-72 ayda başlamasına göre çocuklara daha olumlu yansıdığı görüşündedir. Öğretmenlerin verdiği cevaplar ile demografik özellikleri bakımından karşılaştırıldıklarında; öğretmenlerin cinsiyet, öğrenim durumu, kıdem ve sınıf mevcudu değişkeni bakımından herhangi bir farklılaşma görülmemiş olup mezun oldukları okul türü değişkeni bakımından anlamlı bir fark olduğu görülmüştür.

Anahtar Kelimeler: Okul öncesi eğitim, okul motivasyonu, sınıf kuralları.

\section{Examination of the Effects of Pre-school Education Period on Children's Compliance with Classroom Rules and School Motivations According to Teacher Opinions}

\footnotetext{
ABSTRACT

The objective of this study was to investigate the effects of different durations of pre-school attendance on the academic intrinsic motivation of children as well as their ability to conform the classroom rules based on the data collected from the questionnaires and surveys that were completed by the pre-school teachers. 161 teachers were randomly selected among all preschool teachers employed in private and/or public schools with preschool programs in the Sehitkamil district of the city of Gaziantep. The participants were asked to complete a predesigned survey called "Preschool Teacher Evaluation Scale for Children with Different Age Groups for Starting Pre-School Education" prepared by the researcher. The statistical analysis of the data that was obtained from the questions and the evaluation scale were carried out on IBM SPSS Statistics. First, frequency and percentage analysis were performed in accordance with demographic characteristics of the participants. Second, the frequency and percentage values of the answers of 17 questions that were mentioned above were examined. Lastly, the distribution of data collected from the ordinal scale was examined and the analysis technique of the next step was determined. Following the adjustments in normality, t-test and ANOVA were conducted to elucidate the relationship between different demographics and the response of teachers on the questions that were presented. The results revealed a positive statistical significance in the
} 
interaction of age groups and the overall development of children, indicating an overall greater positive effect on children that start pre-school between the ages of 36 and 48 months when compared to children that start pre-school between the ages of 60 and 72 months. Although the comparison of the demographic variables and the responses to the questions did not reveal a statistical significance in terms of gender, level of education, seniority of the teachers or their class size, the school that the teachers received their degrees from revealed a meaningful effect.

Keywords: Pre-school education, school motivation, classroom rules.

\section{Giriș}

Araştırmacılara göre insan beyni erken yaşlardaki deneyimlere yanıt verir ve çevre zihinsel gelişim için çok önemlidir. Çocuklar dünyaya genetik özellikleri ile gelirler, bu özelliklerdeki potansiyelleri en üst seviyeye çıkarmak sağlanan yaşantılar ile mümkündür. Burada öncelikle ailenin çocuğa uygun bir çevre hazırlayıp onu ilk yıllarda desteklemesi sonraki yıllarda ise okul öncesi kurumda gelişimine uygun zenginleştirilmiş bir çevresel ortamla gelişim sürecini pozitif yönde etkilemek gerekmektedir (Güven ve Efe Azkeskin, 2010). Okul öncesi eğitim formal eğitimin sistemli olarak ilk kademesini oluşturmaktadır. Çocukların kendilerine uygun şekillerde yapılandırılan bir ortam içerisinde, gelişim özelliklerine uygun şekilde hazırlanmış programlar çerçevesinde, akran gruplarının bulunduğu sosyal bir ortamda temel eğitime hazırlanması sağlanır (Şahin, 1998).

Yapılan araştırmalar göstermektedir ki erken çocukluk yıllarında çocuklara uyarıcı bakımından donanımlı ortamlarda bulunmaması çocuğun ilerleyen yıllardaki öğrenme ve gelişim düzenlerine sınırlanmalar yaşanmasına neden olmaktadır. $\mathrm{Bu}$ yıllarda sağlanacak zengin uyarıcı ortamlar ise çocuğun zihinsel kapasitesini arttıracak temel eğitim içerisinde başarılı olmasını sağlayacak ve genel olarak öğrenme düzeylerinde arttırdığı gözlenecektir (Bloom, 1976'dan Akt. Senemoğlu, 2001).

Okul öncesi eğitime verilen önem ülkemizde her geçen yıl artarak devam etmektedir. $\mathrm{Bu}$ konuda Millî Eğitim Bakanlığı (MEB) tarafından organize edilen Millî Eğitim Şuraları incelendiğinde okul öncesi eğitim gündemde artış göstererek ele alınmıştır. Millî Eğitim Şuraları'nda geçmişten günümüze okul öncesi eğitim ile ilgili alınan kararlara bakıldığında:

- V. Millî Eğitim Şurası'nda okul öncesi eğitimden ilk kez bahsetmesi adına önemi büyüktür. Çok büyük kararlar ve uygulamalar olmasa da ilk defa bahsedilmiş olması diğer yııllarda yapılacak olan yenilikler ve düzenlemeler için temel oluşturmuştur (Millî Eğitim Bakanlığı, 1953).

- IX. Millî Eğitim Şurası'nda ilk kez okul öncesi eğitim kapsamlı olarak ele alınmış gerekli açıklamaları ve içerik tanımlamaları yapılmıştır (MEB, 1974).

- X. Millî Eğitim Şurası'nda okul öncesi adına oldukça kapsamlı kararlar alınmış ve zamanla zorunlu eğitim kapsamına alınacağı belirtilmiştir. Ayrıca çocukların aileleri için kaynak materyaller hazırlanması konusu ile aile katılımına ilk kez dikkat çekilmiştir. Aileyi eğitimin içerisine almak ekstra önemi olan bir konu ve bu konu adına ilk kez vurgu yapılan şura 1981 tarihindeki şuradır (MEB, 1981).

- 1982 yılında gerçekleşen XI. Millî Eğitim Şurası'nda “Millî Eğitim hizmetlerinden öğretmen ve eğitim uzmanları (durum ve sorunları)" konusu içerisinde okul öncesi eğitim sistemine öğretmen yetiştiren programların amaçları, ilkeleri ve işlevleri ayrıntılı bir şekilde maddeler üzerinden sunulmuştur (MEB, 1982).

- 1993 yılında gerçekleştirilmiş olan XIV. Millî Eğitim Şurası'nda okul öncesi eğitimin yaygınlaştırılması ve bu konuda yapılacak çalışmalar, anaokulunun ve anasınıfı tanımları ve bu tanımlamadaki fark, okul öncesi kurumda çalışacak personelin niteliği, okul öncesi eğitim adına yapılacak olan çalışmalar ve her türlü gider için kaynak temini, diğer kurum kuruş ve kişilerle yapılacak işbirliği çalışmaları, okul öncesi eğitim mevzuatı, okul öncesi kurumları yanı sıra yine bu yaş grubunda olan çocuklara eğitim veren kreş, bakımevi, çocuk yuvaları ve sosyal tesislere yapılacak teşvik çalışmaları, dünya üzerinde uygulanan farklı okul öncesi modelleri ve uygulamaları, okul öncesi eğitimi destekleyen ve katılımı arttıracak projeler, "okul öncesi eğitim fonu" kurulması, okul öncesi ögretmenlerinin kontenjanlarının artması, 
okul öncesi eğitime uygun materyal ve kitap üretimleri yapan işletmelere yardımlarda bulunacağ 1 gibi kararlar vurgulanmıştır (MEB, 1993).

- XV. Millî Eğitim Şurası'nda okul öncesi eğitimin (5-6 yaş) ilköğretim bünyesine alınması gerektiği, ayrıca ailelere yönelik "Aile Katılım Programları" ve "Ana Baba Okulları" yapılması ve yaygınlaştırılması vurgulanmıştır. Özel gereksinimli çocuklar için fiziki düzenlemeler yapılmasının üzerinde durulmuştur (MEB, 1996).

- XVI. Millî Eğitim Şurası'nda okul öncesi eğitim çağına gelmiş 60-72 ay çocuklar için okul öncesi eğitim zorunluluğu gündeme getirilmesi ve bu konuda çalışmalara başlanması gerektiği vurgulanmıştır. Okul öncesi eğitimde özel sektöre teşviğin artması istenmiştir. Ayrıca kadının çalışma hayatına katılması ile 0-3 yaş çocuklar için kuruma ihtiyacı gün geçtikçe arttığı vurgunlanmış bu sebeple özel sektörün ve devlet kurumlarının eşgüdümlü bir şekilde çalışmasının eğitimin niteliğini arttıracağı belirtilmiştir. "1739 Sayılı Millî Eğitim Temel Kanunu"nda, gerekli düzenlemeler yapılarak, "Okul Öncesi Eğitimi Kanunu" çıkarılması kararlaştırılmıştır. Cumhuriyetin 100. Yılının kutlanacağ 2023 yılı itibari ile 36-60 ay çocuklara, okullaşma oranı \% 80 olarak hedeflenmiştir. Genel bütçe içerisinden okul öncesi eğitime ayrılmış olan katkı artırılmalıdır şeklinde kararlar alınmıştır (MEB, 2006).

- 2010 yılında yapılan XVIII. Millî Eğitim Şurası'nda açık öğretim ya da uzaktan eğitim yolu ile okul öncesi öğretmeni olunamayacağı, alan ile ilgili öğretim elemanı yetiştirilmesi adına çalışmalar yapılması gerektiği, yakın dönem hedefleri içerisinde okul öncesi eğitimin zorunluluk kapsamına alınacağı, okul öncesi eğitime ayrılan ödeneğin arttırılması gibi kararlar alınmıştır (MEB, 2010).

Şuralarda alınan kararlar incelendiğinde zamanla okul öncesi eğitimin çok önemli bir parçası haline geldiği görülmektedir. Okul öncesi eğitimin zamanla zorunlu eğitim kapsamında alınması şuralarda tekrar tekrar ele alınmıştır. Ayrıca okul öncesi eğitime ayrılan ödenekte artış olması ve desteklenmesi hususu farklı yıllardaki şuralara gündem olmuştur.

Türkiye'nin okul öncesi eğitim istatistiklerine bakıldığında, 2009 y1lından 2017 y1lına kadar okul öncesi eğitime katılma oranlarında artış mevcuttur (MEB, 2018). Bunun sebebi okul öncesi eğitime verilen önemin artması, ailelerin bilinçlenmesi, kadının çalışma hayatına girmesi ile çocuğa yeni bir eğitim alanı arayışına girilmesi, değişen çağımızda ailenin zengin uyarıcı ortamlara ihtiyaç duyması gibi sebepler olabilir. Bu artış1 devlet politikaları da etkilemiş olabilir. Okul öncesi eğitimin zorunlu eğitim kapsamına alınması adına yapılan çalışmalar, anaokulu ve anasınıflarının yaygınlaşması, bu konuda projeler yapılması, okul öncesi eğitime ulaşamayan çocuklar için sunulan fırsatlar vs. eğitimin zaman içinde ulaşabildiği çocuk sayısını arttırmış olabilir.

Tablo 1

Okul Öncesi Ĕ̈itimde Yillara Göre Mevcut Okul, Öğretmen, Şube, Ögrrenci Saylsı *

\begin{tabular}{ccccccrrr} 
Öğretim & Okul/ & \multicolumn{3}{c}{ Öğretmen } & \multicolumn{3}{c}{ Şube } & Öğrenci \\
& Sınıf & Toplam & Erkek & Kadın & & Toplam & Erkek & Kadın \\
\hline $2003-2004$ & 13285 & 17511 & 694 & 16817 & 16710 & 344741 & 179988 & 164753 \\
$2004-2005$ & 15978 & 22152 & 1161 & 20991 & 31547 & 434771 & 226959 & 207812 \\
$2005-2006$ & 18553 & 20910 & 1167 & 19743 & 31511 & 550146 & 286347 & 263799 \\
$2006-2007$ & 20675 & 24775 & 1181 & 23594 & 36654 & 640849 & 334252 & 306597 \\
$2007-2008$ & 22506 & 25901 & 1218 & 24683 & 40857 & 701762 & 366209 & 335553 \\
$2008-2009$ & 23653 & 29342 & 1644 & 27698 & 45030 & 804765 & 421033 & 383732 \\
$2009-2010$ & 26681 & 42716 & 2069 & 40647 & 53235 & 980654 & 511127 & 469527 \\
$2010-2011$ & 27606 & 48330 & 3414 & 44916 & 57707 & 1115818 & 580296 & 535522 \\
$2011-2012$ & 28625 & 55883 & 2954 & 52929 & 61937 & 1169556 & 607052 & 562504 \\
$2012-2013$ & 27197 & 62933 & 3620 & 59313 & 61920 & 1077933 & 562179 & 515754 \\
$2013-2014$ & 26698 & 63327 & 3387 & 59940 & 63273 & 1059495 & 555194 & 504301 \\
$2014-2015$ & 26972 & 68038 & 4070 & 63968 & 67387 & 1156661 & 607247 & 549414 \\
$2015-2016$ & 27793 & 72228 & 3871 & 68357 & 71003 & 1209106 & 633349 & 575757 \\
$2016-2017$ & 28891 & 76384 & 4032 & 72352 & 75942 & 1315854 & 688517 & 627337 \\
$(1 . d o ̈ n e m)$ & & & & & & & & \\
\hline
\end{tabular}




\begin{tabular}{lllllllll}
\hline $2016-2017$ & 29293 & 77109 & 4429 & 72680 & 76783 & 1326123 & 693179 & 632944 \\
$2017-2018$ & 31246 & 84257 & 4585 & 79672 & 84637 & 1501088 & 782646 & 718442 \\
\hline
\end{tabular}

*(MEB, 2018)

Tablo 1 incelendiğinde 2003-2004 y1lları ile 2017-2018 y1lları arasında: mevcut okul/sınıf sayılarında yaklaşık 2,5 kat artış yaşandığı görülmektedir. oplam öğretmen sayısı yaklaşık 4,8 kat artarken; erkek öğretmenlerdeki artış oranı yaklaşık 6,6 kat kadın öğretmen artış oranı yaklaşık 4,7 olarak bulunmuştur. Şube sayısında yaklaşık 5 katın üzerinde bir artış olduğu gözlenmiştir. Toplam öğrenci sayısında ise yaklaşık 4,3 kat artış yaşanırken bu artış kız ve erkek öğrenciler için yine yaklașık 4,3 kat artış olduğu tabloda verilen rakamlara göre hesaplanmaktadır. Verilere bakıldığında düzenli olmasa da genel olarak her yıl artış gözlenmektedir. Fakat 2012-2013 yılında bir dalgalanma yaşanmıştır. $\mathrm{Bu}$ yıllarda yaşanan gelişmelere bakıldığında eğitim zorunlu olarak 12 seneye çıkarılmıştır. Bu durumun etkisinin bir yansıması olarak düşünülebilir. Bunun dışında yaşanan farklara bakıldığında yıllar içerisinde en çok artış erkek öğretmen oranında olmuştur. Bunun sebebi olarak da başlangıçta okul öncesi öğretmenliğinin kadınlara daha uygun bir meslek olması önyargısının insanlar tarafindan benimsenmesi olabilir. Günümüzde yine oran olarak eğitim fakültelerinde erkek okul öncesi öğretmenliği öğrencileri ve kurumlarda çalışan erkek öğretmen sayısı kadın öğretmen sayısına oranla oldukça düşüktür ama yıllar geçtikçe erkek öğretmen sayısının artacağı düşünülmektedir. Okul öncesi eğitimden yararlanan öğrencilerin cinsiyetlerine göre sayılara bakıldığında y1llar içerisinde sürekli bir artış gözlenmiştir. Fakat dikkat çeken bir durum vardır ki her y1l okul öncesi eğitim alan erkek öğrenci sayısı kız öğrenci sayısından daha fazla bulunmuş̧ur. Okul öncesi eğitimden maksimum yararlanma sağlamak adına çalışmalar sürdürülmektedir. $\mathrm{Bu}$ konuda yapılan bazı çalışmalar: yeni eğitim kurumları açılmaya devam etmektedir, okul öncesi öğretmeni atamaları yüksek oranlarla sürdürülmektedir, farklı projelerle okul öncesi eğitimden yararlanamayan çocuklara ulaşılmaya çalışılmaktadır, ayrıca yine okul öncesi eğitimden faydalanamamış çocuklar için yaz okulları sürdürülmektedir. Buradaki amaç okul öncesi eğitimden faydalanan çocuk sayısını maksimum seviyeye çıkarmak, zamanla okul öncesi eğitimi zorunlu eğitim kademelerinin içerisine almaktır.

Okul öncesi eğitimin önemi eğitim kademelerimiz içerisinde önemi her geçen gün artmaktayken Türk Millî Eğitim Sistemi'nde okul öncesi eğitime dair yapılan araştırmalar incelendiğinde, okul öncesi eğitimin süresi konusunda öğretmenler ile yapılan bir çalışmaya rastlanmamıştır. Bu nedenle yapılan bu araştırma okul öncesi eğitim süresine dair öğretmen fikirlerini alan ilk çalışma olma niteliğindedir. Toplanan veriler ışığında farklı sürelerde okul öncesi eğitim almış çocukların okul kurallarına uyum ve okul motivasyonlarının ne şekilde etkilendiğini konusunda; okul öncesi öğretmenlerinin görüşleri alınarak var olan durumun belirlenmesi, sorunların tespiti ve çözüm önerilerinin ortaya koyulması amaçlanmaktadır

\section{Yöntem}

\section{Araştırmanın Modeli}

Betimsel bir çalışma olan bu araştırmada tarama modeli kullanılmıştır. "Tarama modelleri, geçmişte olmuş veya şu anda var olmaya devam eden durumu olduğu haliyle betimlemeyi amaçlar. Araştırmaya konu olan durum, kişi veya nesne var olduğu gibi tanımlanır. Herhangi bir şekilde değiştirilmez ya da etkilenmez" (Karasar, 2008, s. 77).

\section{Evren ve Örneklem}

Yapılan araştırmanın evrenini Gaziantep ili Şehitkamil ilçesinde Millî Eğitim Bakanlığına ait anaokulu ve anasınıflarında çalışan okul öncesi öğretmenleri oluşturmaktadır. Araştırmanın örneklemini ise seçkisiz örnekleme yolu ile seçilen 161 okul öncesi öğretmeni oluşturmaktadır. Tablo 2 'de araştırmaya katılan örneklemin demografik özeliklerinin frekans ve yüzde değerleri verilmiştir. 
Tablo 2

Araştırmaya Katılan Öğretmenlerin Demografik Özellikleri

\begin{tabular}{cccc}
\hline & Grup & $\mathrm{F}$ & $\%$ \\
\hline \multirow{3}{*}{ Cinsiyet } & Kadın & 143 & 88.2 \\
& Erkek & 18 & 11.8 \\
& Toplam & 161 & 100 \\
\multirow{3}{*}{ Öğrenim Düzeyi } & Önlisans & 36 & 22.4 \\
& Lisans & 107 & 66.5 \\
& Yüksek Lisans & 18 & 11.2 \\
Mezun Olunan Okul Türü & Toplam & 161 & 100 \\
& Okul Öncesi Öğretmenliği & 99 & 61.5 \\
& Çocuk Gelişimi & 62 & 38.5 \\
& Toplam & 161 & 100 \\
\multirow{2}{*}{ Kıdem } & $1-5$ yll & 81 & 50.3 \\
& $6-10$ yıl & 55 & 34.5 \\
& 11 y1l & 25 & 15.6 \\
& Toplam & 161 & 100 \\
& $10-14$ kişi & 34 & 21.1 \\
Sinıf Mevcudu & $15-19$ kişi & 52 & 32.3 \\
& $20-24$ kişi & 54 & 33.5 \\
& $25-29$ kişi & 21 & 13.0 \\
& Toplam & 161 & 100 \\
\hline
\end{tabular}

Araştırmaya katılan öğretmenlerden kadınların oranı \%88.8 iken erkeklerin oranı \%11.2; $\% 22.4$ 'ü ön lisans, \%66.5'i lisans, \%11.1'i yüksek lisans mezunu olarak bulunmuştur. Katılımciların \%61.5'inin okul öncesi öğretmenliği mezunu, \%38.5'unun çocuk gelişimi mezunu; öğretmenlerin $\% 50.3$ 'ünün 1-5 yıl aras1, \%34.5'inin 6-10 y1l aras1, \%15.6'sının ise 11 yıl ve üzeri meslek hayatında bulunduğu görülmektedir. 10-14 kişilik sinıfta öğretmenlik yapanlar \%21.1, 15-19 kişilik sınıfta öğretmenlik yapanlar \%32.3, 20-24 kişilik sınıfta öğretmenlik yapanlar \%33.5, 25-19 kişilik sınıfta öğretmenlik yapanlar ise \%13.0 olarak bulunmuştur.

\section{Verilerin Toplanması}

\section{Veri Toplama Aracı}

Veriler araştırmacı tarafından geliştirilen "Okul Öncesi Eğitim Süresinin Çocuklara Etkisine Dair Öğretmen Görüşleri Ölçeği” ile toplanmıştır.

\section{Okul Öncesi Ĕ̆itim Süresinin Çocuklara Etkisine Dair Öğretmen Görüşleri Ölçeğinin Geliştirilme Süreci}

Ölçeğin birinci bölümünde okul öncesi eğitime 36-48 ayda ya da 60-72 ayda başlamış çocuklara yönelik karşılaştırma içeren 17 adet soru; yapılan literatür taramasında, benzer konularda yapılan çalışmalardan ve okul öncesi öğretmenleri ile yapılan görüşmeler sonucunda hazırlanmıştır. Uzman görüşleri alınarak maddelerin kapsam ve yapı geçerliliği sağlanmıştır.

Ölçeğin ikinci bölümünde beşli likert tipinde 13 adet soru sorulmuştur. Bu sorular hazırlanırken başlangıçta 15 adet okul öncesi öğretmeni ile okul öncesi eğitim süresi ile ilgili fikir alışverişinde bulunulmuştur. Öğretmenler ile yapılan olan görüşmeler, alanla ilgili yapılan literatür taramalarından ayrıca benzer konular için oluşturulmuş olan ölçeklerden yardım alınarak ölçek için bir havuz oluşturulmuştur. Bir sonraki aşamada 18 maddelik soru grubu oluş̧urulmuştur. Bu soru grubu alanda çalışan 2 öğretim üyesine danışılmış ve bazı eksiklikleri giderilmiştir. İmla ve yazım hatalarını gidermek adına Türkçe öğretmenlerine danışılıp düzeltmeler yapılmıştır. Sonrasında ise bir grup okul öncesi öğretmenine maddelerin açı ve anlaşılır olup olmadığ 1 sorulmuş ve anlaşılmayan maddeler alanda uzman öğretim elemanlarının de görüşleri alınarak yeniden düzenlenmiştir. Bunların sonuncunda 5 madde ölçekten çıkarılarak 13 maddelik bölüm oluşturuluştur. Okul Öncesi Eğitim 
Süresinin Çocuklara Etkisine Dair Öğretmen Görüşleri Ölçeği ikinci bölümünün geçerlik ve güvenirlik çalışmalarına Gaziantep Şehitkamil ilçesinde 152 öğretmen katılmıştır.

\section{Açımlayıcı Faktör Analizi}

Okul Öncesi Eğitim Süresinin Çocuklara Etkisine Dair Öğretmen Görüşleri Ölçeği ikinci bölümünün faktör analizi öncesi toplanan verilerin boyut analizine uygun olup olmadığına bakmak için Kaiser - Meyer - Olkin (KMO) katsayısı hesaplanmış ve Barlett's Sphericity testi uygulanmıştır.

Tablo 3

Okul Öncesi Eğitim Süresinin Çocuklara Etkisine Dair Öğretmen Görüşleri Ölçeği İkinci Bölümü Kaiser-Meyer-Olkin Örneklem Ölçüm ve Barlett's Sphericity Testi Sonuçları

Kaiser - Meyer - Olkin

Örneklem Ölçüm Yeterliği

.886

Barlett's Testi Yaklaşık

$\mathrm{Ki}$ - Kare Değeri

$1103.715 \quad \mathrm{Sd}=78 \quad \mathrm{p}=.000$

Ulaşılan verilere göre KMO katsayısı .886 olarak bulunmuştur. Bulunan sonuç yani $.886>.60$ olduğu için veriler boyut analizine uygun (Büyüköztürk, 2006) olarak bulunmuştur. Ayrıca, Barlett küresellik testi değeri $(X 2=1103.715, \mathrm{p}<.01)$ anlamlı olarak bulunmuştur. Bulunan değerler sonucunda değişkenlerin arasında korelasyonun yüksek olduğu ve toplanmış olan verilerin boyut analizi için uygun olduğunu görülmektedir.

Temel bileşenleri bulmak adına dik döndürme tekniği uygulanmıştır. Öz değeri 1'den daha fazla bulunan boyutlar Kaiser kuralına göre dikkate alınır (Şencan, 2005). Buradan yola çıkarak ölçeğin açıklamış olduğu toplam varyansa bakıldığında öz değeri 1'den daha yüksek olan tek faktör olduğu bulunmaktadır. Burada faktör sayısını belirlemek adına bakılması gerekilen diğer bir konu ise bulunan farktörlerin toplam varyansa katkılarıdır (Çokluk, Şekerci ve Büyüköztürk., 2010). Tablo 4 'te tek boyuta ait değerler gösterilmiştir. Tablo 4'e bakıldığında tek faktörün varyansa yaptığı katkı \% $47.755^{\prime}$ tir.

Tablo 4

Okul Öncesi Ĕ̈itim Süresinin Çocuklara Etkisine Dair Öğretmen Görüşleri Ölçeği İkinci Bölümü Tek Faktöre Yönelik Yük Değerleri

\begin{tabular}{cccc}
\hline Faktör & Özdeğer & Varyans Yüzdesi & Toplam Varyans Yüzdesi \\
\hline 1 & 6.208 & 47.755 & 47.755 \\
\hline
\end{tabular}

Tek boyutlu bir çalışma olduğu için toplam varyans yüzdesi de \% 47.755 oranındadır. Ayrıca maddelerin öz değerlerine göre çizilmiş olan grafik de boyutların sayısına karar vermek için önemli olduğundan çizgi grafiğine bakılmıştır.

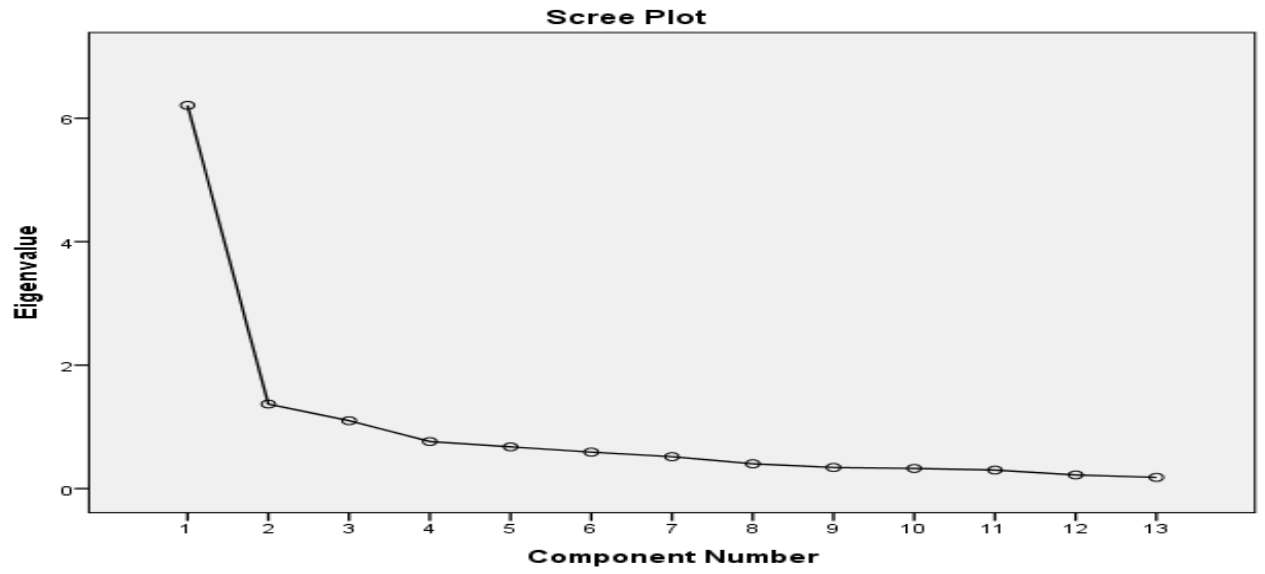

Grafik 1. Okul Öncesi Eğitim Süresinin Çocuklara Etkisine Dair Öğretmen Görüşleri Ölçeği İkinci Bölümü Maddelerin Öz Değerleri 
Boyutların varyansa yaptıkları katkıya bakıldığında tek bir boyut olarak oluşturulması uygun görülmüş̧ür. Ölçekte bulunan 13 adet maddeye döndürülmüş temel bileşenler testi yapılmıştır. Tek boyutlu yapıdaki maddelerin faktör yükleri Tablo 5 'te gösterilmiştir.

Tablo 5

Okul Öncesi Eğitim Süresinin Çocuklara Etkisine Dair Öğretmen Görüşleri Ölçeği İkinci Bölümü Açımlayıcı Faktör Analizi

Madde Faktör yükü

\begin{tabular}{ll}
\hline M10 & .822 \\
M5 & .812 \\
M7 & .795 \\
M9 & .781 \\
M6 & .766 \\
M3 & .734 \\
M8 & .728 \\
M11 & .702 \\
M4 & .666 \\
M1 & .600 \\
M13 & .538 \\
M12 & .531 \\
M2 & .530 \\
\hline
\end{tabular}

Tablo 5'e bakıldığında tüm maddelerin tek faktör altında toplandığı görülmektedir. Faktör yükü 0.30 'dan daha az olan madde bulunmadığından 13 adet madde ölçekte kullanılmıştır.

\section{Doğrulayıcı Faktör Analizi}

Açımlayıcı faktör analizi sonuçlarında bulunan boyutların yapısal olarak uygunluğunun belirlenmesi için LISREL programı ile ölçeğe doğrulayıcı faktör analizi uygulanmıştır.

Tablo 6

Okul Öncesi Eğitim Süresinin Çocuklara Etkisine Dair Öğretmen Görüşleri Ölçeği İkinci Bölümüne İlişkin Önerilen Modelin Uyum Değerleri

\begin{tabular}{lc}
\hline Uyum Ölçüleri & Okul Öncesi Eğitim Süresinin Çocuklara Etkisine \\
& Dair Öğretmen Görüşleri Ölçeği \\
\hline SRMR & 0.0774 \\
GFI & 0.785 \\
AGFI & 0.699 \\
NNFI & 0.783 \\
CFI & 0.819 \\
$X^{2}$ & 272.08 \\
\hline
\end{tabular}

Tablo 6'ya bakıldığında doğrulayıcı faktör analizi sonuçlarına göre, elde edilen uyum indeksi değerleri $\mathrm{X}^{2}=272.08, \mathrm{GFI}=0.785, \mathrm{AGFI}=0.699, \mathrm{CFI}=0.819, \mathrm{NNFI}=0.783, \mathrm{SRMR}=0.0774$ olarak hesaplanmıştır.

$\mathrm{X}^{2}$ oranının serbestliğe oranı yani $\mathrm{X}^{2 /} \mathrm{sd}=4.18$ olarak bulunmuştur. Bulunan değerin 5 'ten daha küçük olması modelin yeterli düzeyde uygun olduğunu göstermektedir (Sümer, 2000). Tablo 6'da bulunan SRMR değerlerine bakıldığında 0.1'den daha küçük olarak bulunmuştur. Bu da bulunan değerlerin "kabul edilebilir" olduğunun göstergesidir (Y1lmaz ve Çelik, 2009).

CFI, GFI, AGFI VE NNFI değerleri 0 ile 1 rakamları arasında değerler almıştır. Önerilen modelin 1'e yakın olması modelin mükemmel uyum gösterdiğinin diğer bir kanıtıdır (Sümer, 2000). Analizler sonucunda çıkan verilere göre boyut yapısının veriler ile uyum gösterdiği kanıtlanmaktadır. Okul öncesi eğitim süresinin çocuklara etkisine dair öğretmen görüşleri ölçeğine ait gizil değişkenlerin, gözlenen değişkenleri açıklayabilme oranının anlamlı fark düzeyi şekil 1'de gösterilmektedir. 


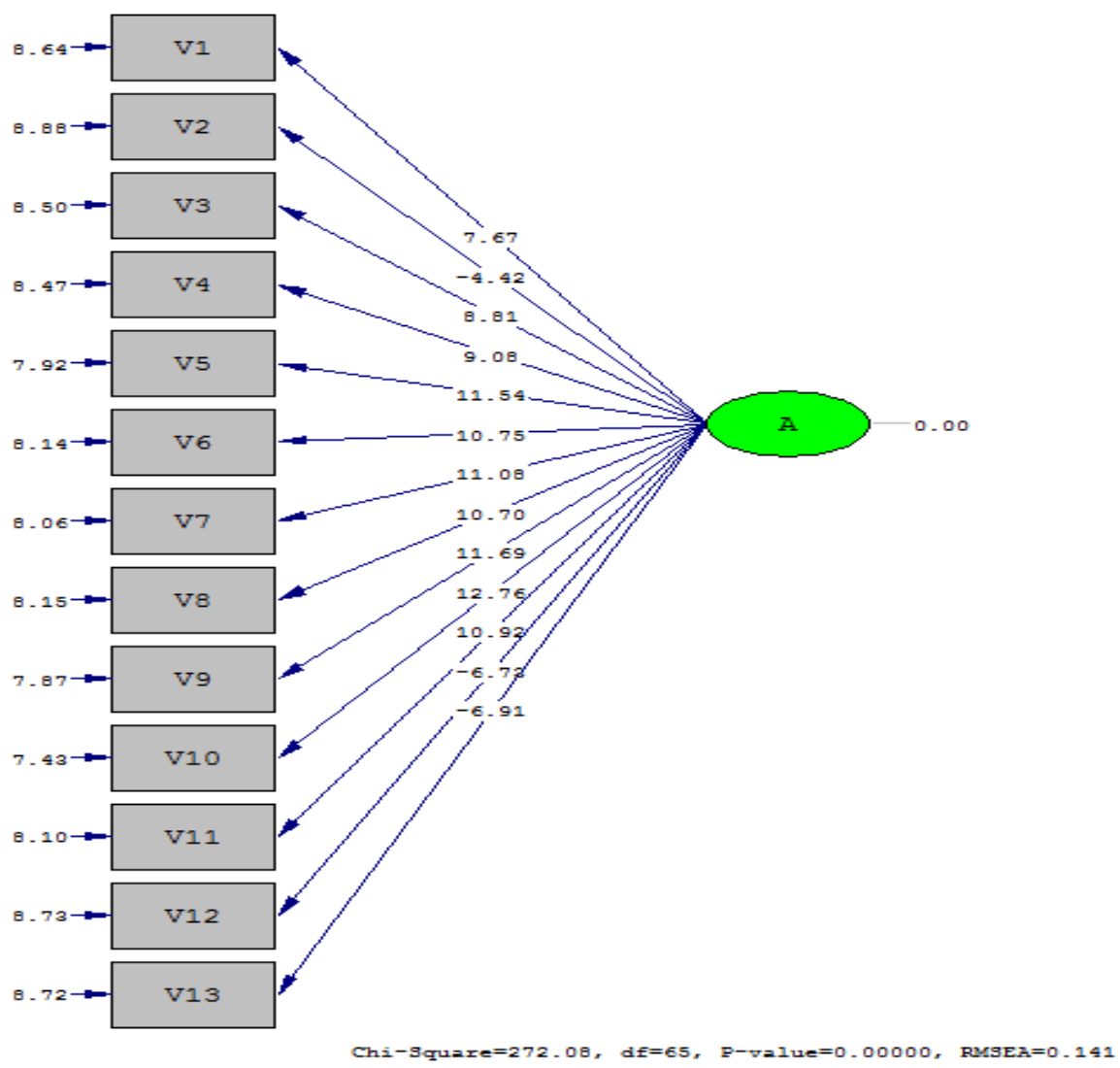

Şekil 1. Okul Öncesi Eğitim Süresinin Çocuklara Etkisine Dair Öğretmen Görüşleri Ölçeği İkinci Bölümüne Dair Gizil Değişkenlerin, Gözlenen Değişkenleri Açıklayabilme Oranlarının Anlamlı Fark Düzeyi

Şekil 1'e bakıldığında gizil olan değişkenlerin, gözlenebilir değişkenleri açıklayabilme durumlarına yönelik olan değerler oklar ile belirtilmiştir. Manidarlık durumuna bakıldığında: $\mathrm{T}$ değerlerinin 1.96 'dan büyük olduğunda .05 düzeyinde, 2.56 'dan büyük olması durumunda ise .01 seviyesinde manidar sayılmaktadır (Çokluk, Şekerci ve Büyüköztürk., 2010). Şekil 1'e bakıldığında maddelerin hepsinin .01 seviyesinde manidar $\mathrm{t}$ değeri bulunmuştur. $\mathrm{T}$ değerlerinin manidarlık durumlarına bakıldıktan diğer şart olan hata varyanslarına bakılmıştır. 


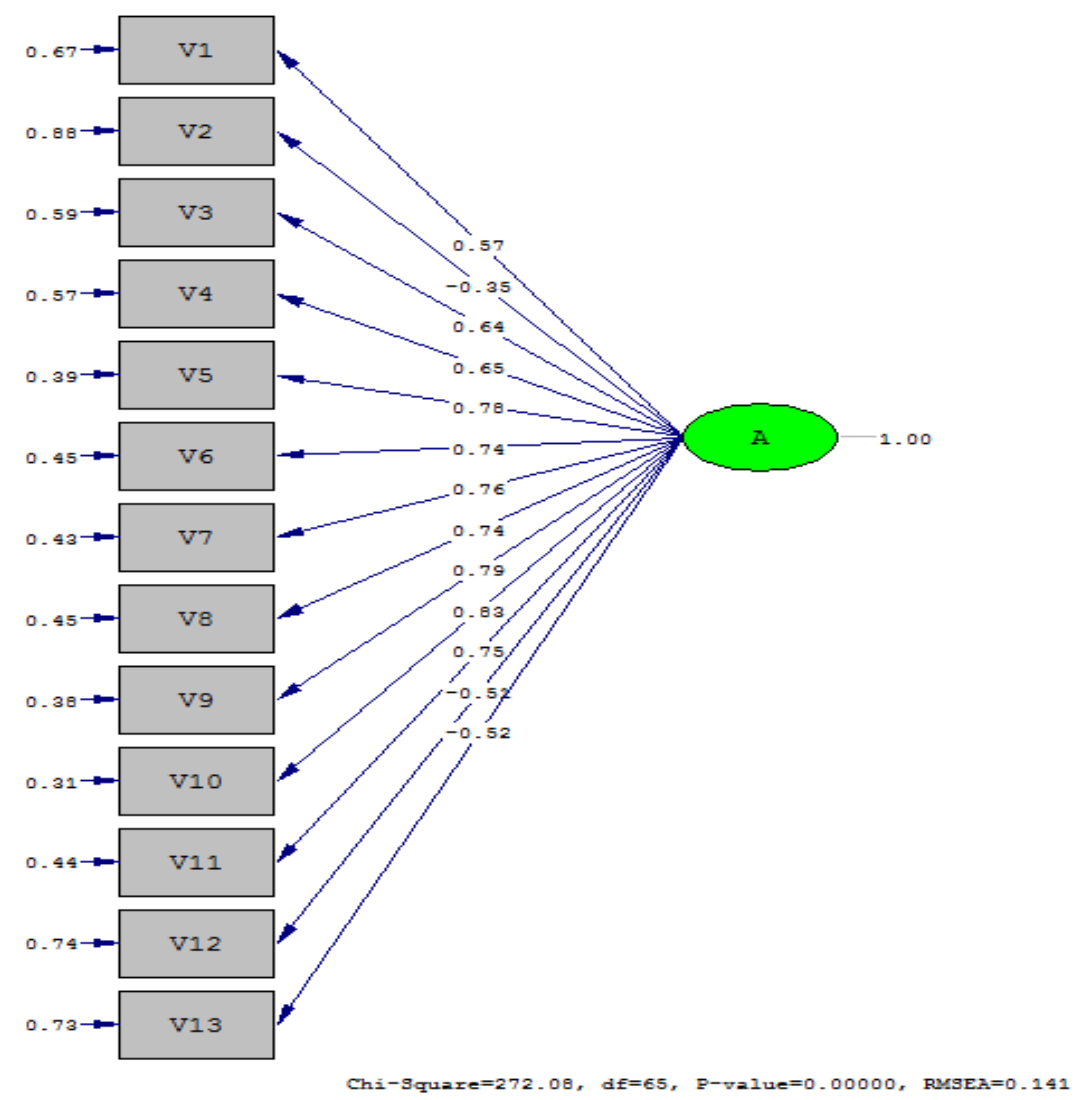

Şekil 2. Okul Öncesi Eğitim Süresinin Çocuklara Etkisine Dair Öğretmen Görüşleri Ölçeği İkinci Bölümüne Ait Hata Varyansları

Şekil 2'de verilen değerlere bakıldığında en yüksek hata varyansının V12 için .74, en düşük hata varyansının V10 için .30 olarak hesaplanmıştır. Maddelerin hepsine bakıldığında modelin hata varyansı açısından uygun bulunduğu görülmektedir.

Okul Öncesi Eğitim Süresinin Çocuklara Etkisine Dair Öğretmen Görüşleri Ölçeği ikinci bölümü üzerinden yapılan geçerlilik hesaplamalarından sonra bütünü tek boyutta geçerli bulunmuştur. Tek boyutta oluşturulan Okul Öncesi Eğitim Süresinin Çocuklara Etkisine Dair Öğretmen Görüşleri Ölçeği ikinci bölümü için hesaplanmış olan Cronbach Alpha güvenirlik katsayısı 0.798 olarak hesaplanmıştır. Bu değer 0.60-0.80 arasında bulunduğu için ölçek "oldukça güvenilir" (Kalayc1, 2009) bulunmuştur. Sonuç olarak geçerliliği ve güvenilirliği test edilmiş Okul Öncesi Eğitim Süresinin Çocuklara Etkisine Dair Öğretmen Görüşleri Ölçeği iki bölüm şeklinde geliştirilmiştir. Ölçeğin birinci bölümü okul öncesi eğitimin süresine ilişkin 17 adet sorudan, ikinci bölümü ise tek boyutta 13 maddeden oluşmaktadır.

\section{Verilerin Analizi}

Ölçeğin "Okul Öncesi Eğitim Süresinin Çocuklara Etkisine Dair Öğretmen Görüşleri Ölçeği”" birinci bölümünde hazırlanmış olan sorular SPSS Paket Programı kullanılarak yüzdeleri ile frekans değerleri hesaplanmıştır. "Okul Öncesi Eğitim Süresinin Çocuklara Etkisine Dair Öğretmen Görüşleri Ölçeği” ikinci bölümde hazırlanan sorular SPSS Paket Programı kullanılarak araştırmaya katılanların demografik verilerine göre farklılaşma durumları, yüzde ve frekans değerleri hesaplanmıştır. Okul Öncesi Eğitim Süresinin Çocuklara Etkisine Dair Öğretmen Görüşleri Ölçeği’nin ikinci bölümündeki sorular beşli likert tipi ölçek şeklindedir. Ölçekteki ifadeler: "Kesinlikle Katılmıyorum", "Katılmıyorum", "Fikrim Yok", "Katılıyorum" ve "Kesinlikle Katılıyorum" şeklinde ifade edilmiştir. Ölçek içindeki olumlu maddeler sırası ile kodlanmış olup olumsuz olarak belirlenen 3, 12 ve 13. maddeler için tersten (5-4-3-2-1) kodlama yapılmıştır. 
Tablo 7

Okul Öncesi Eğitim Süresinin Çocuklara Etkisine Dair Öğretmen Görüşleri Ölçeği İkinci Bölümü Madde Değer Aralıklart

\begin{tabular}{lcc}
\hline Değer Aralığı & $\begin{array}{c}\text { Katılım Düzeyi } \\
\text { (olumlu ifadeler için) }\end{array}$ & $\begin{array}{c}\text { Katılım Düzeyi } \\
\text { (olumsuz ifadeler için) }\end{array}$ \\
\hline $1.00-1.80$ & Kesinlikle katılmıyorum & Tamamen katılıyorum \\
$1.81-2.60$ & Katılmıyorum & Katıllyorum \\
$2.61-3.40$ & Kararsızım & Kararsızım \\
$3.41-4.20$ & Katılıyorum & Katılmıyorum \\
$4.21-5.00$ & Tamamen katılıyorum & Kesinlikle katılmıyorum \\
\hline
\end{tabular}

Araştırmada ulaşılan verilerin geçerlilik ve güvenilirlik durumlarına bakıldıktan sonra verilerin analizinde hangi testlerin kullanılacağına dair ölçeğe normallik testi yapılmıştır. Test sonucunda ölçeğin çarpıklık ve basıklık değerlerine göre normal dağılım olup olmadığına bakılmıştır.

Tablo 8

Okul Öncesi Eğitim Süresinin Çocuklara Etkisine Dair Öğretmen Görüşleri Ölçeği İkinci Bölümü Çarpıklık ve Basıklık Değerleri

\begin{tabular}{lccc}
\hline & Kişi Sayısı & Basıklık & Çarpıklık \\
\hline Ölçek Puanları & 161 & -.023 & -.811 \\
\hline
\end{tabular}

George ve Mallery (2010) basıklık ve çarpıklık değerlerinin -2 ile +2 arası değer alması olmas normalliğin göstergesidir. Tablo 8'e bakıldığında Okul Öncesi Eğitim Süresinin Çocuklara Etkisine Dair Öğretmen Görüşleri Ölçeği ikinci bölümünün çarpıklık değeri -.811, basıklık değeri -.023 olarak bulunmuştur. Buna göre ölçek normal dağılım göstermektedir. Ölçek içerisinde kullanılan değişkenlerde cinsiyet ve mezun olunan okul türü değişkeninde bağımsız gruplar için t-Testi; kıdem, sınıf mevcudu ve öğrenim düzeyi değişkenleri için tek yönlü varyans analizi yani ANOVA testi uygulanmıştır.

\section{Bulgular}

\section{Okul Öncesi Eğitim Süresinin Çocuklara Etkisine Dair Öğretmen Görüşleri Ölçeği Birinci Bölüme İlişkin Görüşlerin Analizi}

Tablo 9'da öğretmenlerin, ölçeğin birinci bölümünde sorulmuş sorulara vermiş oldukları cevapların frekansları ve yüzdelik dağılımları verilmiştir.

Tablo 9

Okul Öncesi Eğitim Alma Sürelerinin Öğrencilere Etkisine Dair Sorulara Verilen Cevapların Frekanslarl ve Yüzdelik Değerleri

\begin{tabular}{|c|c|c|c|c|}
\hline & \multicolumn{2}{|c|}{$\begin{array}{c}\text { 36-48 ayda okul } \\
\text { öncesi kuruma } \\
\text { başlamış çocuk için }\end{array}$} & \multicolumn{2}{|c|}{$\begin{array}{c}\text { 60-72 ayda okul } \\
\text { öncesi kuruma } \\
\text { başlamış çocuk için }\end{array}$} \\
\hline & $\mathrm{F}$ & $\%$ & $f$ & $\%$ \\
\hline G1: Okulun ilk günlerinde okula daha istekli gelir. & 101 & 62.7 & 60 & 37.3 \\
\hline G2: Başlangıçta okula alışma zorluğu daha çok yaşa. & 39 & 24.2 & 122 & 75.8 \\
\hline G3: Daha çok sosyal uyumsuzluk yaşar. & 41 & 25.5 & 120 & 74.5 \\
\hline G4: Arkadaşları ile daha iyi ilişkiler kurar. & 129 & 80.1 & 32 & 19.9 \\
\hline G5: Etkinliklerde daha istekli davranır. & 100 & 62.1 & 61 & 37.9 \\
\hline G6: Okulun ilk günlerinde huzursuz davranışlar sergiler. & 44 & 27.3 & 117 & 72.7 \\
\hline G7: Okulun eğlenceli bir yer olduğunu daha çok düşünür. & 106 & 65.8 & 55 & 34.2 \\
\hline G8: Okula gelmemek için daha çok bahane üretir. & 58 & 36.0 & 103 & 64.0 \\
\hline G9: Okula daha çok ailelerin isteği ile gelir. & 76 & 47.2 & 85 & 52.8 \\
\hline G10: Gelişim alanlarında daha çok başarı gösterir. & 125 & 77.6 & 36 & 22.4 \\
\hline
\end{tabular}




\begin{tabular}{lcccc}
\hline G11: Kuralların koyulmasında daha çok fikir beyan eder. & 129 & 80.1 & 32 & 19.9 \\
G12: Kuralları daha çok ve daha iyi bilir. & 128 & 79.5 & 33 & 20.5 \\
G13: Kurallara uyulmadığında sonuçlarını daha çok bilir. & 128 & 79.5 & 33 & 20.5 \\
G14: Kurallara daha kolay uyum gösterir. & 128 & 79.5 & 33 & 20.5 \\
G15: Okul düzenine daha çabuk uyum gösterir. & 130 & 80.7 & 31 & 19.3 \\
G16: Özgüven ve tek başına iş yapabilme becerisi daha & 135 & 83.9 & 26 & 16.1 \\
yüksektir. & & & & \\
G17: İletişim kurma becerisi daha yüksektir. & 133 & 82.6 & 28 & 17.4 \\
\hline
\end{tabular}

Maddelere genel olarak bakıldığında: G4, G11, G15, G16 ve G17 maddelerine katılımcıların \%80'i ve üzeri, okul öncesi eğitime erken yaşta başlayan çocuklar için uygun bulmuşlardır. G12, G13, G14 maddelerine de katılımcıların \%79.5'u okul öncesi eğitime erken yaşta başlayan çocuklar için uygun olduğunu ifade etmişlerdir. Bu bulgular 1şığında maddelerin de ortak özelliklerine bakılarak okul öncesi eğitime erken yaşta başlanması genellikle çocukların: arkadaşları ile daha iyi ilişki kurmalarını, kuralların koyulmasında daha çok fikir beyan etmelerini, kuralları daha iyi bilmelerini, kuralara daha iyi uyum sağlamalarını, kurallara uyulmadığında sonuçlarını daha iyi bilmelerini, okul düzenine daha kolay uyum sağlamalarını, iletişim becerisinin daha yüksek olmasını, özgüven ve tek başına iş yapabilme becerilerinin yüksek olmasını sağlar şeklinde yorum yapılabilir. G2, G4, G6 maddelerine bakıldığında katılımcıların \%70 ve üstü okula 60-72 ayda başlayan çocuklar için uygun bulmuştur. Bu bulgular 1şığında ise okul öncesi eğitime 1 yıl katılan çocuklar daha erken yaşlarda okula başlamış çocuklara oranla okula alışma zorluğunu daha çok yaşaması ve bununla birlikte huzursuz davranışlar sergileme ve sosyal olarak ilişkilerinde uyumsuzluk yaşaması gibi davranışların daha çok görülebileceği yorumu yapılabilir. Erken yaşta okul öncesi eğitime başlayan çocukların okula daha kolay alıştığını, sosyal uyumsuzlukları daha az yaşadığını, ilk günlerde daha az huzursuz davranışlar gösterdiği belirtilebilir.

\section{Okul Öncesi Eğitim Süresinin Çocuklara Etkisine Dair Öğretmen Görüşleri Ölçeği İkinci Bölümüne Verilen Yanıtlara İlişkin Analizler}

Araştırmanın bu başlı̆̆ında ölçeğin ikinci bölümünde öğretmenlere sorulmuş olan sorular ile okul öncesi öğretmenlerinin okul öncesi eğitim süresinin öğrencilere etkisi hakkında düşünceleri öğretmenlerin: Cinsiyetlerine göre, Mezun oldukları bölüme göre, Kıdemlerine göre, Öğrenim düzeylerine göre ve Sinıf mevcutlarına göre görüsslerinde anlamlı bir farklılaşma var mıdır? sorularına göre sıra ile sunulmuştur. Maddelerin istatistik değerlerine ve değişkenlerin farklılaşma durumlarına bakılmadan önce ölçek maddelerinin frekans ve yüzde değerleri hesaplanmış ve yorumlanmıştır.

Tablo 10

Okul Öncesi Eğitim Süresinin Çocuklara Etkisine Dair Öğretmen Görüşleri Ölçeği İkinci Bölümü Aritmetik Ortalama ve Standart Sapma Değerleri

\begin{tabular}{lcc}
\hline & $\overline{\mathrm{x}}$ & Ss \\
\hline Ölçek Toplam & 3.9298 & .72805 \\
\hline
\end{tabular}

Tablo 10'da Okul Öncesi Eğitim Süresinin Çocuklara Etkisine Dair Öğretmen Görüşleri Ölçeği içerisinde verdikleri yanıtlara göre ölçeğin toplamının ortalamasına bakıldığında $\bar{x}=3.9298$ (15 arası) olarak bulunmuştur. Yani araştırmaya katılan öğretmenler Okul Öncesi Eğitim Süresinin Çocuklara Etkisine Dair Öğretmen Görüşleri Ölçeği ikinci bölümü değer aralıklarına bakıldığında ölçekteki sorulara ortalama olarak "katıllyorum" şeklinde değerlendirmişlerdir.

\section{Okul Öncesi Eğitim Süresinin Çocuklara Etkisine Dair Öğretmen Görüşleri Ölçeği İkinci Bölümü Maddelerin İstatistik Değerleri}

Tablo 11'de Okul Öncesi Eğitim Süresinin Çocuklara Etkisine Dair Öğretmen Görüşleri Ölçeği'nin ikinci bölümündeki maddelere verilen yanıtların dağılımlarına göre frekans ve yüzde değerleri, ortalamaları ve standart sapmaları verilmiştir. 
Tablo 11

Okul Öncesi Eğitim Süresinin Çocuklara Etkisine Dair Öğretmen Görüşleri Ölçeği İkinci Bölümü Maddelerinin; Frekans, Yüzde, Standart Sapma ve Aritmetik Ortalama Değerleri

\begin{tabular}{|c|c|c|c|c|c|c|c|c|c|c|c|c|}
\hline & \multicolumn{2}{|c|}{$\begin{array}{c}\text { Kesinlikle } \\
\text { Katılmiyorum }\end{array}$} & \multicolumn{2}{|c|}{ Katılmiyorum } & \multicolumn{2}{|c|}{ Kararsızım } & \multicolumn{2}{|c|}{ Katılıyorum } & \multicolumn{2}{|c|}{$\begin{array}{c}\text { Kesinlikle } \\
\text { Katıliyorum }\end{array}$} & \multirow[t]{2}{*}{$\overline{\mathrm{x}}$} & \multirow[t]{2}{*}{ Ss } \\
\hline & $\mathrm{F}$ & $\%$ & $f$ & $\%$ & $f$ & $\%$ & $f$ & $\%$ & $f$ & $\%$ & & \\
\hline M1 & 2 & 1,2 & 19 & 11.8 & 8 & 5.0 & 54 & 33.5 & 78 & 48.4 & 4.1615 & 1.04822 \\
\hline M2 & 10 & 6.2 & 37 & 23.0 & 14 & 8.7 & 37 & 23.0 & 63 & 39.1 & 3.6584 & 1.36063 \\
\hline M3 & 28 & 17.4 & 64 & 39.8 & 13 & 8.1 & 37 & 23.0 & 19 & 11.8 & 3.2795 & 1.31440 \\
\hline M4 & 3 & 1.9 & 10 & 6.2 & 7 & 4.3 & 51 & 31.7 & 90 & 55.9 & 4.3354 & 0.95488 \\
\hline M5 & 3 & 1.9 & 41 & 25.5 & 23 & 14.3 & 56 & 34.8 & 38 & 23.6 & 3.5280 & 1.16223 \\
\hline M6 & 3 & 1.9 & 27 & 16.8 & 9 & 5.6 & 63 & 39.1 & 59 & 36.6 & 3.9193 & 1.12347 \\
\hline M7 & 2 & 1.2 & 42 & 26.1 & 19 & 11.8 & 69 & 42.9 & 29 & 18.0 & 3.5031 & 1.10184 \\
\hline M8 & 5 & 3.1 & 16 & 9.9 & 3 & 1.9 & 69 & 42.9 & 68 & 42.2 & 4.1118 & 1.05471 \\
\hline M9 & 0 & 0 & 13 & 8.1 & 0 & 0 & 62 & 38.5 & 86 & 53.4 & 4,3727 & 0.85015 \\
\hline M10 & 3 & 1.9 & 16 & 9.9 & 7 & 4.3 & 64 & 39.8 & 71 & 44.1 & 4.1429 & 1.01770 \\
\hline M11 & 2 & 1.2 & 10 & 6.2 & 4 & 2.5 & 64 & 39.8 & 81 & 50.3 & 4.3168 & 0.89038 \\
\hline M12 & 52 & 32.3 & 75 & 46.6 & 12 & 7.5 & 16 & 9.9 & 6 & 3.7 & 3.9379 & 1.06471 \\
\hline M13 & 46 & 28.6 & 75 & 46.6 & 10 & 6.2 & 25 & 15.5 & 5 & 3.1 & 3.8199 & 1.10617 \\
\hline
\end{tabular}

Maddeler incelendiğinde araştırmaya katılan öğretmenlerin görüşlerine göre okul öncesi eğitimin erken yaşta başlamasının çocuklara olumlu olarak yansıdığı yorumunu yapabiliriz. Erken yaşta okul öncesi eğitime başlamanın çocuklar için farklı alanlarda olumlu durumlar oluşturacağını düşünmüşlerdir. Maddelerin istatistiksel verileri incelendiğinde bazı maddeler 4.20 değerinin üzerinde yani ölçek değer aralıklarında kesinlikle katılıyorum değer aralığına denk gelmiştir. Bu maddeler: Okul öncesi eğitimin süresi uzadıkça çocukların sosyal iliş̧kileri kurma becerisi artar. Okul öncesi eğitime katılma süresi arttıkça çocuklar gelişim alanlarında daha başarılı olur. Okul öncesi eğitimi uzun süre almış çocuklar kurallara uymamanın doğuracağ s sonuçlar bilir. Maddelere verilen cevaplara bakıldığında ölçeğin katılmıyorum değer aralığında olan olumsuz maddelerin olduğu görülmektedir. "Okul öncesi eğitimin süresi uzadıkça çocukların istenmeyen davranışları sergileme düzeyi artar." ve "Çocukların okul öncesi eğitim süresi uzadıkça ögretmen ile çocuk arasında otorite sorunu yaşanma riski artar." ifadelerinin ortalamalarına bakıldığında ölçek değer aralıklarında katılmıyorum değer aralığında bulunmuştur. Ayrıca diğer bir olumsuz ifade olan "Okul öncesi eğitimin süresi uzadıkça çocuk okuldan sıkılır." ifadesinin ortalamas 1,22 olarak bulunmuş ve madde bu ortalama ile kararsızım değer aralığında bulunmaktadır. Maddelere bakıldığında çocuğun eğitim süresi ile okuldan sıkılma durumları arasındaki ilişkide ortalama olarak kararsız kalmışlardır. Fakat eğitim süresinin uzamasının otorite sorunlarına yol açacağı ve istenmeyen davranışları sergileme düzeyini arttıracağı maddesine olarak katılmamışlardır.

\section{Okul Öncesi Eğitim Süresinin Çocuklara Etkisine Dair Öğretmen Görüşleri Ölçeği İkinci Bölümünün Değişkenlere Göre Farklılaşma Durumu}

Araştırmada cinsiyet ve mezun olunan bölüm değişkeni için bağımsız gruplar için t-Testi analizi, öğrenim düzeyi kıdem ve sınıf mevcudu değişkenleri için tek yönlü varyans analizi ANOVA'ya bakılmıştır.

Tablo 12’de araştırmaya katılan öğretmenlerin cinsiyetlerine göre analiz değerleri verilmiştir.

Tablo 121

Okul Öncesi Öğretmenlerinin Okul Öncesi Eğitim Alma Süresinin Öğrencilere Etkisi Hakkındaki Düşüncelerinin Cinsiyetlerine Göre Farklılaşma Durumu

\begin{tabular}{lcccccc}
\hline & $\mathrm{N}$ & $\overline{\mathrm{x}}$ & $\mathrm{Ss}$ & $\mathrm{T}$ & $\mathrm{Sd}$ & $\mathrm{P}$ \\
\hline Kadın & 143 & 3.55 & .53849 & -.522 & 159 & 0.602 \\
Erkek & 18 & 3.62 & .46639 & & & \\
\hline
\end{tabular}


Tablo 12'de araştırmaya katılmış kadın öğretmenlerin ortaması 3.55, erkek öğretmenlerin oralaması 3.62 olarak bulunmuştur. Değerler arasında anlamlı fark olup olmadığına bakabilmek için yapılan t-Testi sonuçlarına bakıldığında p değeri 0.602 olarak bulunmuştur. Bu değer .05'ten büyük olarak bulunduğundan katılımcıların cinsiyetleri arasında sorulara verilen yanıtlarda anlamlı bir fark olmadığı belirlenmiştir. Ortalamalara bakıldığında erkek öğretmenlerin ortalamasının kadın öğretmenlere oranla anlamlı olmasa da daha yüksek olduğu görülmektedir.

\section{Okul Öncesi Eğitim Süresinin Çocuklara Etkisine Dair Öğretmen Görüşleri Ölçeği İkinci Bölümünün Mezun Oldukları Okul Türü Değişkenine Göre Farklılaşma Durumu}

Tablo 13'de araştırmaya katılan öğretmenlerin mezun oldukları okul türüne göre analiz değerleri verilmiştir.

Tablo 13

Okul Öncesi Öğretmenlerinin Okul Öncesi Eğitim Alma Süresinin Öğrencilere Etkisi Hakkındaki Düşüncelerinin Mezun Oldukları Okul Türüne Göre Farklılaşma Durumu

\begin{tabular}{lcccccc}
\hline & $\mathrm{N}$ & $\overline{\mathrm{x}}$ & $\mathrm{Ss}$ & $\mathrm{T}$ & $\mathrm{sd}$ & $\mathrm{P}$ \\
\hline Okul öncesi & 99 & 3.48 & .56879 & -2.390 & 159 & 0.018 \\
Öğretmenliği & & & & & & \\
Çocuk Gelişimi & 62 & 3.68 & .43770 & & & \\
\hline
\end{tabular}

Tablo 13'de araştırmaya katılmış olan okul öncesi öğretmenliğinden mezun olanların cevaplarına bakıldığında 3.48 ortalamaya, çocuk gelişimi mezunlarına bakıldığında ise 3,68 ortalamaya sahip oldukları görülmektedir. Mezun olunan okul türü değişkenine göre öğretmen görüşleri arasında farklılaşma olup olmadığına bakmak için yapılan t-Testi sonuçlarına bakıldığında $\mathrm{p}=0.018$ olarak bulunmuştur. Bu değer .05 'ten küçük bulunduğundan katılımcıların mezun oldukları okul türlerine göre sorulara verilen yanıtlarda anlamlı bir fark bulunmuştur. Ortalamalara bakıldığında çocuk gelişimi mezunu öğretmenlerin ortalamasının anlamlı olmasa da yüksek olduğu görülmektedir.

\section{Okul Öncesi Eğitim Süresinin Çocuklara Etkisine Dair Öğretmen Görüşleri Ölçeği İkinci Bölümünün Öğrenim Düzeyi Değişkenine Göre Farklılaşma Durumu}

Tablo 14'de öğretmenlerin öğrenim düzeylerine göre betimleyici istatistikleri, tablo $15^{`}$ te ise öğrenim düzeyi değişkine göre ANOVA testi verileri vardır.

Tablo 14

Okul Öncesi Eğitim Süresinin Çocuklara Etkisine Dair Öğretmen Görüşleri Ölçeği İkinci Bölümü Öğrenim Düzeyi Değişkenine Göre Betimleyici İstatistikleri

\begin{tabular}{lcc}
\hline & $\mathrm{N}$ & $\overline{\mathrm{x}}$ \\
\hline Ön lisans & 36 & 3.70 \\
Lisans & 107 & 3.50 \\
Yüksek Lisans & 18 & 3.56 \\
Toplam & 161 & 3.55
\end{tabular}

Tablo 14'de araştırmaya katılmış olan ön lisans mezunlarının ortalaması 3.70, lisans mezunlarının ortalaması 3.50, yüksek lisans mezunlarının ise ortalaması 3.56 olarak bulunmuştur.

Tablo 15

Okul Öncesi Öğretmenlerinin Okul Öncesi Ĕ̆itim Alma Süresinin Öğrencilere Etkisi Hakkındaki Düşüncelerinin Öğrenim Düzeylerine Göre Farklılaşma Durumu

\begin{tabular}{ccccccc}
\hline & $\begin{array}{c}\text { Kareler } \\
\text { Toplam1 }\end{array}$ & Sd & Kareler Ortalaması & F & p & Fark \\
\hline Gruplar Aras1 & 1.022 & 2 & .511 & 1.838 & .162 & \\
\hline
\end{tabular}




\begin{tabular}{|c|c|c|c|c|}
\hline Gruplar İçi & 43.928 & 158 & .278 & - \\
\hline Toplam & 44.950 & 160 & & \\
\hline
\end{tabular}

Tablo 15 'de “p” değeri 0.162 olduğu görülmektedir. Bu değer .05 'ten büyük olarak bulunduğundan katılımcılar arasında öğrenim düzeyine göre anlamlı bir fark bulunmamıştır. Fakat ortalamalara bakıldığında anlamlı olmasa da ön lisans mezunlarının en yüksek ortalamaya sahip oldukları görülmektedir.

\section{Okul Öncesi Eğitim Süresinin Çocuklara Etkisine Dair Öğretmen Görüşleri Ölçeği İkinci Bölümünün Kıdem Değişkenine Göre Farklılaşma Durumu}

Tablo 16'da öğretmenlerin kıdemlerine göre betimleyici istatistikleri, Tablo 17 'de ise kıdem değişkine göre yapılan ANOVA testinin bulguları yer almaktadır.

Tablo 16

Okul Öncesi Ĕgitim Süresinin Çocuklara Etkisine Dair Öğretmen Görüşleri Ölçeği İkinci Bölümü Kıdem Değişkenine Göre Betimleyici İstatistikleri

\begin{tabular}{lcc}
\hline & $\mathrm{N}$ & $\overline{\mathrm{x}}$ \\
\hline $1-5$ y1l & 81 & 3.56 \\
$6-10$ y1l & 55 & 3.60 \\
$11+$ & 25 & 3.42 \\
Toplam & 161 & 3.55 \\
\hline
\end{tabular}

Tablo 16'te araștırmaya katılmıș olan okul öncesi öğretmenlerinin çalışma hayatında; ilk 5 y1lı içerisinde olanların ortalaması 3.56, 6 ila 10. yıl içerisinde olanların ortalaması 3.60, 11. yıl ve üzeri olanların ortalaması 3.42 olarak bulunmuştur.

Tablo 17

Okul Öncesi Öğretmenlerinin Okul Öncesi Eğitim Alma Süresinin Öğrencilere Etkisi Hakkındaki Düşüncelerinin Kldemlerine Göre Farklılaşma Durumu

\begin{tabular}{|c|c|c|c|c|c|c|}
\hline & $\begin{array}{l}\text { Kareler } \\
\text { Toplamı }\end{array}$ & $\mathrm{Sd}$ & $\begin{array}{c}\text { Kareler } \\
\text { Otalamas1 }\end{array}$ & $\mathrm{F}$ & $\mathrm{P}$ & Fark \\
\hline Gruplar Arası & .598 & 2 & .299 & 1.065 & .347 & \\
\hline Gruplar İçi & 44.352 & 158 & .281 & & & - \\
\hline Toplam & 44.950 & 160 & & & & \\
\hline
\end{tabular}

Tablo 17'de "p" değeri 0.347 olarak görülmektedir. Bu değer .05 'ten büyük olarak bulunduğundan katılımcılar arasında kıdem durumlarına göre anlamlı bir fark bulunmamıştır. Fakat ortalamalara bakıldığında 6-10 yıldır meslek hayatında olan grup ortalaması en yüksek, 11 yıl ve üzeri çalışan grup ortalaması en düşük bulunmuştur.

\section{Okul Öncesi Eğitim Süresinin Çocuklara Etkisine Dair Öğretmen Görüşleri Ölçeği İkinci Bölümünün Sınıf Mevcudu Değişkenine Göre Farklılaşma Durumu}

Tablo 18' de öğretmenlerin sınıf mevcudu durumlarını betimleyici istatistikleri, Tablo 19'da sınıf mevcudu değişkenine göre ANOVA testi bulguları vardır. 
Tablo 18

Okul Öncesi Eğitim Süresinin Çocuklara Etkisine Dair Öğretmen Görüşleri Ölçeği İkinci Bölümü Sınıf Mevcudu Değiş̧kenine Göre Betimleyici İstatistikleri

\begin{tabular}{lcc}
\hline & $\mathrm{N}$ & $\overline{\mathrm{x}}$ \\
\hline $10-14$ kişi & 34 & 3.57 \\
$15-19$ kişi & 52 & 3.56 \\
$20-24$ kişi & 54 & 3.58 \\
$25-29$ kişi & 21 & 3.45 \\
Toplam & 161 & 3.55 \\
\hline
\end{tabular}

Tablo 18'de de araştırmaya katılmış olan okul öncesi öğretmenlerinin sınıf mevcudu durumları incelendiğinde sinıfinda 10-14 çocuk bulunanların ortalaması 3.57, 15-19 çocuk bulunanların ortalaması 3.56, 20-24 çocuk bulunanların ortalaması 3.58 ve 25-29 çocuk bulunanların ortalaması 3.55 olarak bulunmuştur.

Tablo 19

Okul Öncesi Öğretmenlerinin Okul Öncesi Eğitim Alma Süresinin Öğrencilere Etkisi Hakkındaki Düşüncelerinin Sinıf Mevcutlarına Göre Farklılaşma Durumu

\begin{tabular}{lcccccc}
\hline & $\begin{array}{c}\text { Kareler } \\
\text { toplamı }\end{array}$ & Sd & $\begin{array}{c}\text { Kareler } \\
\text { ortalamas }\end{array}$ & F & P & Fark \\
\hline Gruplar Arası & .298 & 3 & .099 & .349 & .790 & - \\
Gruplar İçi & 44.652 & 157 & .284 & & & \\
Toplam & 44.950 & 160 & & & & \\
\hline
\end{tabular}

Tablo 19'a bakıldığında "p" değeri .790 bulunmuştur. Bulunan değerin .05 ten büyük olarak bulunduğu için katılımcılar arasında sınıf mevcudu değişkenine göre anlamlı fark olmadığı görülmektedir. Katılımcıların, sınıf mevcudu değişkenine bakıldığında, sorulara verdiği cevapların ortalamaları da birbirine çok yakın değerlerde bulunmuştur.

\section{Sonuç, Tartışma ve Öneriler}

Okul öncesi öğretmenlerinin, okul öncesi eğitimin süresi hakkında görüşlerini incelemek amacıyla yapılan bu araştırmada araştırmacı tarafından geliştirilen "Okul Öncesi Eğitim Süresinin Çocuklara Etkisine Dair Öğretmen Görüşleri Ölçeği” araştırmaya katılan öğretmenlere uygulanmıştır. Ölçeğin birinci bölümünde okul öncesi öğretmenlerine; okul öncesi eğitim süresi ile ilgili karşılaştırmaya dayalı sorular sorulmuş, cevaplara göre yüzde ve frekans değerleri ile öğretmenlerin görüşleri değerlendirilmiştir. Ölçeğin ikinci bölümünde ise araştırmaya katılan öğretmenlere sorulan likert tipte sorular analiz edilmiş ve değişkenler bazında farklılaşma olup olmadığına bakılmıştır.

Ölçeğin birinci bölümünde uygulanmış olan okul öncesi eğitim süresi ile ilgili karşılaştırmaya dayalı soruların frekans ve yüzde değerleri incelendiğinde görülmüştür ki öğretmenler okul öncesi eğitime 36-48 ayda başlayan çocukların 60-72 ayda okul öncesi eğitime başlayan çocuklara göre genel olarak daha avantajlı bulmuşlardır. Katılımcılar bazı maddeleri yüksek oranda 36-48 ayda okul öncesi eğitime başlamış çocuklar için uygun olarak görmüşlerdir. Verilen cevaplara bakıldığında katılımcıların büyük bir kısmı okul öncesi eğitime 36-48 ayda başlayan çocukların 60-72 ayda başlayan çocuklara göre: arkadaşları ile daha iyi ilişki kurduklarını, kuralların koyulmasında daha fazla fikirlerini beyan ettiklerini, kuralları daha iyi bildiklerini, kuralara daha iyi uyum sağladıklarını, kurallara uyulmadığında sonuçları daha iyi bildiklerini, okul düzenine daha kolay uyum sağladıklarını, iletişim becerilerinin daha yüksek olduğunu, özgüven ve tek başına iş yapabilme becerilerinin daha yüksek olduğunu belirtmişlerdir. Katılımcıların okul öncesi eğitime erken yaşta başlayan çocuklar için yüksek oranda olumlu bulduğu bu maddelere bakıldığında özellikle kurallar konusunda ve sosyal 
alana yönelik olan maddelerde okul öncesi eğitime erken yaşta başlayan çocukları avantajlı bulmuşlardır. Araştırmaya katılan öğretmenlerin okul öncesi eğitime 60-72 ayda başlayan çocukların 36-48 ayda başlayan çocuklara göre: başlangıçta okula alışma zorluğunu daha çok yaşadıklarını, daha çok sosyal uyumsuzluk yaşadıklarını, okulun ilk günlerinde huzursuz davranışları daha çok sergilediklerini ifade etmişlerdir. Öğretmenlerin görüşlerine göre; okul öncesi eğitime daha geç başlayan çocukların okula alışma ve uyum sağlama davranışlarında okul öncesi eğitime erken başlayan çocuklara göre daha dezavantajlı olarak görülmüştür.

Ölçeğin ikinci bölümünde katılımcılara sorulan likert tipte sorular ile araştırmanın amaçlarından biri olan okul öncesi öğretmenlerinin okul öncesi eğitim süresine bakış açısı değerlendirmeye çalışılmıştır. Sorulara verilen cevapların ortalama değerlerine bakıldığında, araştırmaya katılan öğretmenler cevaplara ortalama olarak "katılıyorum" cevabını vermişlerdir. Bu değere göre öğretmenler okul öncesi eğitimin erken yaşta başlamasına genel olarak olumlu olarak bakmaktadırlar.

Ölçeğin ikinci bölümüne verilen cevaplara göre katılımcıların değişkenler bazında farklılaşma yaşayıp yaşamadıklarına bakılmıştır. Cinsiyet, öğrenim düzeyleri, kıdemleri, sınıf mevcudu değişlenlerine göre öğretmenlerin verdiği cevaplara bakıldığında anlamlı bir fark bulunmamışken mezun oldukları okul türü değişkenine göre anlamlı bir fark olduğu görülmüş ve çocuk gelişimi mezunlarının ortalaması daha yüksek olarak bulunmuştur.

Kazu ve Yılmaz (2018) Türkiye'deki okul öncesi eğitim ile OECD ve AB ülkelerini karşılaştıran bir araştırma yapmışlardır. Veriler incelendiğinde 2014 yılına ait; 3 yaş, 4 yaş ve 5 yaş okul öncesi eğitime katılım oranlarında Türkiye diğer ülkelerin oldukça gerisinde kalmaktadır. Özellikle 3 yaş okullaşma oranında OECD ve AB ülkelerinde okullaşma oranı \%70 civarında bulunmuşken Türkiye'de aynı oran \%10 civarı olduğu görülmektedir. MEB (2018) kaynakları incelendiğinde yıllar içerisinde okul öncesi eğitime katılımın ve ayrılan katkının arttığı gözlemlenmektedir. Yapılan şuralara ve alınan kararlara bakıldığında da okul öncesi eğitimin zorunluluk kapsamına alınması hedeflenmektedir. Okul öncesi dönem içerisinde çocuğun nitelikli bir eğitim alması onu temel eğitimin diğer basamaklarına çok daha donanımlı bir şekilde hazırlayacaktır. Verilere bakıldığında ülkemiz okul öncesi eğitim katılımı gelişmiş ülkelere oranla çok daha düşük olsa da planlamalar çerçevesinde geliştirilmeye ve her çocuğa ulaşılmaya çalışılmaktadır.

$\mathrm{Bu}$ araştırma sonucunda öğretmenlerin genel görüşlerine bakıldığında okul öncesi eğitimin erken yaşta başlaması farklı nitelikler bakımından çocuklara olumlu bir şekilde yansımaktadır. 36-48 ayda okul öncesi eğitim kurumuna giden çocuklar sonraki yıllarda okul öncesi eğitime katılan çocuklara göre bazı konularda daha avantajlı bulunmuşlardır.

Araştırma bulguları kapsamında yapılan öneriler:

- Okul öncesi eğitimin zorunlu olması adına çalışmalar hızlandırılabilir.

-Okul öncesi eğitimin daha uzun süreli ve her çocuğa ulaşması için çalışmalar arttırılabilir.

-Eğitim fakülteleri okul öncesi öğretmenliği ders içerikleri 60-72 ay arası çocuklara yönelik olmaktan ziyade 3,4 ve 5 yaş için farklı ders içerikleri hazırlanabilir.

•Okul öncesi öğretmenlerine yönelik 36-48, 48-60, 60-72 ay çocuklar için gelişim özelliklerine uygun etkinlik kitapları hazırlanıp, öğretmenlere bu konuda kaynak sağlanabilir.

-Öğretmenlere farklı yaş gruplarına eğitim sürecinde en verimli şekilde nasıl çalışabileceğine dair hizmet içi eğitimler verilebilir.

-Okul öncesi eğitim süresi ile ilgili farklı başlıklar altında nitel araştırmalar arttırılabilir.

-Okul öncesi eğitim süresi ile ilgili yapılan bu araştırma Gaziantep ili Şehitkamil ilçesi ile sınırlandırılmıştır. Benzer araştırmalar farklı bölgelerde yapılarak bu konuda öğretmenlerin düşüncesi hakkında farklılıklar karşılaştırılabilir.

-Araştırmada sadece okul öncesi öğretmenlerinin fikirleri alınmıştır. Araştırmaya alanda çalışan öğretim elemanları ve lisans öğreniminin son sınıfında olan stajyer öğrenciler ile yapılarak daha farklı sonuçlara ulaşılabilir. 
Açıklamalar: $\mathrm{Bu}$ çalışma ikinci yazarın danışmanlığında birinci yazarın hazırladığı "Okul Öncesi Eğitim Alma Süresinin Çocukların Sınıf Kurallarına Uyum ve Okul Motivasyonlarına Etkisinin Öğretmen Görüşlerine Göre İncelenmesi” isimli Yüksek Lisans tezinden üretilmiştir.

\section{Kaynaklar}

Büyüköztürk, Ş. (2006). Veri analizi el kitabı (6. Bask1.). Ankara: Pegem A Yayınc1lık.

Çokluk, Ö., Şekerci, G. ve Büyüköztürk, Ş. (2010). Sosyal bilimler için çok değişkenli istatistik: SPSS ve LISREL uygulamalart. Ankara: Pegem Akademi.

George, D. and Mallery, M. (2010). SPSS for windows step by step: A simple guide and reference, 17.0 update (10a ed.). Boston: Pearson.

Güven, G. ve Efe Azkeskin, K. (2010). Erken çocukluk eğitimi. İ. H. Diken (Ed.), Erken çocukluk eğitimi ve okul öncesi eğitim. Ankara: Pegem Akademi.

Kalaycı, Ş. (2009). SPSS uygulamalı çok değişkenli istatistik uygulamaları. Ankara: Asil Yayinevi.

Karasar, N. (2008). Bilimsel araştırma yöntemi (18. Baskı). Ankara: Nobel Basım Dă̆ııtım.

Kazu, İ. Y. ve Yılmaz, M. (2018). Ülkemizdeki okul öncesi eğitimin bazı veriler açısından OECD ve AB üyesi ülkeleri ile karşılaştırılması. Turkish Journal of Educational Studies, 5(2), 64-75.

MEB. (1953). $\quad 5 . \quad$ Millî Eğitim

https://ttkb.meb.gov.tr/meb_iys_dosyalar/2017_09/29164807_5_sura.pdf 20.12.2018 tarihinde erişilmiştir.

MEB. $\quad$ (1974). $\quad 9.9$ Millî https://ttkb.meb.gov.tr/meb_iys_dosyalar/2017_09/29165045_9_sura.pdf 20.12.2018 tarihinde erişilmiştir.

MEB. $\quad$ (1981). $10 . \quad$ Millî $\quad$ Eğitim https://ttkb.meb.gov.tr/meb_iys_dosyalar/2017_09/29165120_10_sura.pdf 20.12.2018 tarihinde erişilmiştir.

MEB. (1982). $11 . \quad$ Millî https://ttkb.meb.gov.tr/meb_iys_dosyalar/2017_09/29165200_11_sura.pdf 20.12.2018 tarihinde erişilmiştir.

MEB. (1993). $14 . \quad$ Millî Eğitim http://ttkb.meb.gov.tr/meb_iys_dosyalar/2017_09/29165401_14_sura.pdf 20.12.2018 tarihinde erişilmiştir.

MEB. $\quad$ (1996). $15 . \quad$ Millî https://ttkb.meb.gov.tr/meb_iys_dosyalar/2017_09/29165430_15_sura.pdf 20.12.2018 tarihinde erişilmiştir.

MEB. (2006). 17. Millî Eğitim Şuras https://ttkb.meb.gov.tr/meb_iys_dosyalar/2017_09/29165619_17_sura.pdf 20.12.2018 tarihinde erişilmiştir. Suras1. adresinden

Şuras1. adresinden

Şuras1. adresinden

Şuras1. adresinden

Şuras1. adresinden

Şuras1. adresinden

Kararları. adresinden 
MEB. (2010).

18. Millî

Eğitim

Şuras1

Kararları.

https://ttkb.meb.gov.tr/meb_iys_dosyalar/2017_09/29170222_18_sura.pdf adresinden 20.12.2018 tarihinde erişilmiştir.

MEB. (2018). Millî eğitim istatistikleri örgün eğitim 2017- 2018. Ankara: Resmi İstatistik Program 1 Yayın1. https://sgb.meb.gov.tr/meb_iys_dosyalar/2018_09/06123056_meb_istatistikleri_orgun _egitim_2017_2018.pdf . adresinden 06.03.2019 tarihinde erişilmiştir.

Senemoğlu, N. (2001). Çocuk hakları, çalışan çocuklar ve eğitim sorunları. Millî Eğitim Dergisi. Sayı: 151. http://dhgm.meb.gov.tr/yayimlar/dergiler/milli_egitim_dergisi/151/senemoglu.htm adresinden 09.01.2019 tarihinde erişilmişsir.

Şahin, F. (1998). Okul öncesinde Fen Bilgisi öğretimi. İstanbul: Beta Yayınclık.

Şencan, H. (2005). Sosyal ve davranışsal ölçümlerde güvenilirlik ve geçerlilik. Ankara: Seçkin.

Sümer, N. (2000). Yapısal eşitlik modelleri: temel kavramlar ve örnek uygulamalar. Türk Psikoloji Yazıları, 3(6), 49-74.

Yılmaz, V. ve Çelik, H. E. (2009). Lisrel ile yapısal eşitlik modellemesi-I: Temel kavramlar, uygulamalar, programlama. Ankara: Pegem Akademi Yayınc1lik. 


\section{Extended Abstract}

\section{Introduction}

Preschool education constitutes the first stage of formal education. It is ensured for children to be prepared for basic education with coeval groups and in a social environment that is structured to suit them (Şahin, 1998). Referring to Turkey's pre-school education statistics, from 2009 to 2017 increase in the rate of participation in pre-school education is observed (MEB, 2018). This increase may also have been influenced by government policies. The studies carried out in order to incorporate preschool education into compulsory education, augmenting and enhancing of kindergartens, opportunities for children who do not have access to preschool education may have increased the number of children that education can reach. While the importance of preschool education is increasing day by day, no research has been found in Turkish National Education System which is done with teachers about the duration of pre-school education. Because of this reason, this study is the first study to get the ideas of teachers about pre-school education period. It is aimed that identifying the problems and suggesting solutions by taking the opinions of the preschool teachers and by using obtained datas about how school motivation and compliance with school rules are affected pre-school children at different times.

\section{Method}

161 teachers were randomly selected among all preschool teachers employed in private and/or public schools with preschool programs in the Sehitkamil district of the city of Gaziantep, Turkey. The participants were asked to complete a predesigned survey called "Preschool Teacher Evaluation Scale For Children With Different Age Groups For Starting Pre-School Education" prepared by the researcher. The statistical analysis of the data that was obtained from the questions and the evaluation scale were carried out on IBM SPSS Statistics for Windows, version 21(IBM Corp., Armonk, N.Y., USA). First, frequency and percentage analysis were performed in accordance with demographic characteristics of the participants. Second, the frequency and percentage values of the answers of 17 questions that were mentioned above were examined. Lastly, the distribution of data collected from the ordinal scale was examined and the analysis technique of the next step was determined. Following the adjustments in normality, t-test and ANOVA were conducted to elucidate the relationship between different demographics and the response of teachers on the questions that were presented.

\section{Results}

Teachers participating in the research stated that children who start pre-school education in 60-72 months had more difficulty than children who start pre-school education in 36-48 months in getting used to school at the beginning. They experience more social inconsistencies and they exhibited more restless behaviors in the first days of school. According to teachers' opinions; children who started to preschool education in 60-72 months were more disadvantaged in their habituation and adaptation behaviors compared to children who started education earlier. Most of participants indicated that children who start pre-school education in 36-48 months have a better relationship with their friends, they express their opinion in the establishment of rules, they know and compliance with the rules better, they know the results better if the rules are not followed, they have easier adaptation to the school layout, they have higher communication skills, they have higher self-confidence and ability to do business alone. By considering the positive observations, especially on obeying rules and social cases, it is found that who start pre-school education in 36-48 months have an advantage over children who start pre-school education in 60-72 months. Although the comparison of the demographic variables and the responses to the questions did not reveal a statistical significance in terms of gender, level of education, seniority of the teachers or their class size, the school that the teachers received their degrees from revealed a meaningful effect. 


\section{Discussion and Conlusion}

Having qualified education during the preschool period, will prepare children in a much more equipped way for the other stages of basic education. Although our country's participation in preschool education is much lower than in developed countries, it is planned to augment and enhance kindergartens and to reach every child. Kazu and Yilmaz (2018) conducted a study that compares preschool education in Turkey and in the OECD and the EU countries. By examining data, it is seem that in 2014 for 3 years, 4 years and 5 years old children preschool education participation rate in Turkey falls far behind other countries. Especially enrollment rate for 3 years old children in OECD and EU countries was around $70 \%$, meanwhile same rate in Turkey is observed about $10 \%$. By examining the sources of MEB (2018), it is observed that the participation and contribution of pre-school education increased over the years. According to decisions taken in council meetings, it is seen that incorporating preschool education into compulsory education is aimed. As a result of this research, the general opinions of teachers shows that to start pre-school education in early ages effects children positively in terms of different qualities. Children who attended pre-school education in 36-48 months were found more advantageous than children who started pre-school education later. Therefore the importance given to pre-school education should be raised and ongoing works on incorporating preschool education into compulsory education should be expedited. Studies to reach every children on procuring pre-school education should be carried on. Studies on different topics related to the duration of pre-school education are needed to be increased. 